\title{
DIATOM, CONTRIBUTORS OF CORALLOID SPELEOTHEMS, FROM TOGAWA-SAKAIDANI-DO CAVE IN MIYAZAKI PREFECTURE, CENTRAL KYUSHU, JAPAN
}

\author{
Naruhiko Kashima ${ }^{\star}$, Teruo Irie ${ }^{\star \star}$ and Nobuhiro Kinoshita *
}

\section{SUMMARY}

Coralloid speleothems are commonly distributed in Togawa-Sakaidani-do Cave in Miyazaki Prefecture, Central Kyushu, but their speleological study has not heretofore been achieved. Light and scanning microscopes analyses revealed that coralloid speleothems consist of alternating layers of diatom colonies, detrital minerals and clay. Electron microprobe analysis shows coralloid speleothems to be siliciferous.

This paper assert that diatom (genus Melosira) is one of the important contributors to siliceous coralloid speleothems in the threshold zone at noncalcareous caves.

\section{INTRODUCTION}

At the start of this study, Mr. T. IRIE, one of the writers, found the curious coralloid speleothems $2-3 \mathrm{~cm}$ in hight and $0.5-1 \mathrm{~cm}$ in diameter from Togawa-Sakaidani-do Cave. The powder X-ray diffractive pattern of coralloid speleothems contains no mineral peaks. The other hand, this specimen is unreactive to hydrochloric acid.

Recently, the writers visited Togawa-Sakaidani-do Cave for a resurvey of coralloid speleothems, and reexamined by light and scanning microscopes and electron microprobe analysis.

The purpose of this paper is to report on a detailed nature of newly discovered diatomaceous coralloid speleothems from the noncalcareous cave.

\footnotetext{
* Department of Geology, Faculty of General Education, Ehime University 3 Bunkyo-cho, Matsuyama, Ehime 790, Japan.

* * Cave Research Group of Kumamoto c/o 2-19-11 Ikeda, Kumamoto, Kumamoto 860, Japan.
} 


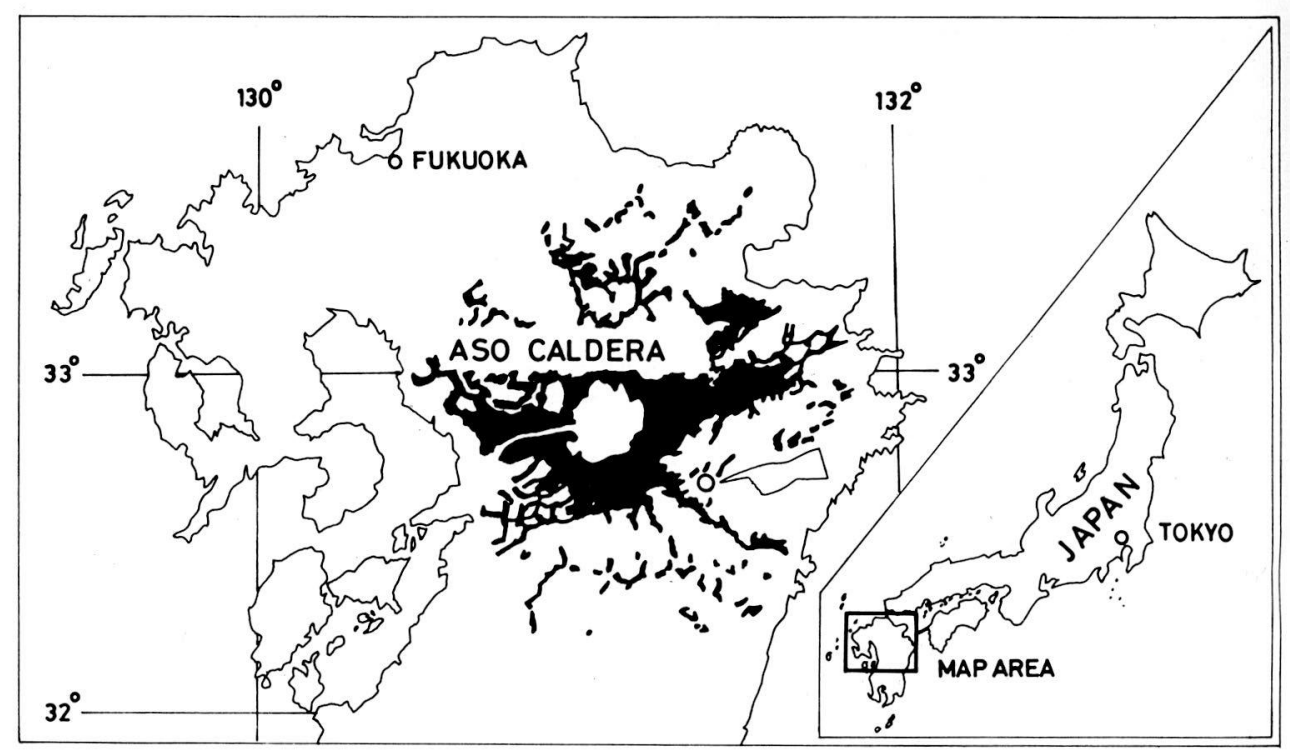

Fig. 1 - Locality map shown in the portion of cave studied. Aso pyroclastic flows in black.

\section{STUDIED CAVE AND CORALLOID SPELEOTHEMS}

The geological survey of this area was carried by Metallic Minerals Exploration Agency of Japan in 1967-1968. The stratigraphy of the studied are consists of 1) the mainly Permian strata are made up of slate, sandstone, conglomerate, chert, limestone and greenstones, so-called the KiuraTogawa facies of southern subbelt of the Chichibu Belt unconformably overlain by 2) the Quaternary Aso pyroclastic flows.

Togawa-Sakaidani-do Cave is located near the south boundary of the Aso pyroclastic flows which is distributed along a small tributary of the Hinokage River, at latitude: $32^{\circ} 42^{\prime} 07^{\prime \prime} \mathrm{N}$ and longitude: $131^{\circ} 23^{\prime} 53^{\prime \prime} \mathrm{E}$ (Fig. 1).

Erosive Togawa-Sakaidani-do Cave entirely developed in the lowest part of the Aso pyroclastic flows. The cave entrance lies about $75 \mathrm{~m}$ above the water of the Hinokage River and opens the foot of the active water fall that hangs on the edge of the Aso pyroclastic flows.

Coralloid speleothems described here, were distributed on the cave ceiling, walls and on the surfaces of breakdown blocks in the threshold zone and characteristically oriented with respect to the cave entrance. 


\section{ANALYTICAL RESULTS}

In light microscopic observation of the thin sections of coralloid speleothems, they apparently had constructed with concentric different colored layers of diatom colonies, detrital minerals and alternate clay in the growth crust.

By scanning microscopic scrutinies, coralloid speleothems are revealed to be encrustes of diatom colonies. These diatom specimens identified with a genus Melosira sp. in their general clindrical morphology, their cell size up to 0.02-0.03 mm wide, and their cell frameworks; surface sculptures and thorny cell terminals (Figs. 2, 3).

Results of electron microprobe analysis of diatom cells are given Table 1. Analysis of 8 specimens were resting yielded mean chemical values of $91.7 \%$ for $\mathrm{SiO}_{2}, 1.08 \%$ for $\mathrm{Al}_{2} \mathrm{O}_{3}, 0.17 \%$ for $\mathrm{FeO}$ and $0.06 \%$ for $\mathrm{CaO}$.

\section{CONCLUSIVE REMARKS}

The nature and distribution of the flora in the cave environment was described by CuBBon (1976). Summarized discussion has been given to the influence the activity of microorganisms such as bacteria, algae and fungi may exert over the contruction of speleothems by HILL and FORTI (1986).

Table 1 - Electron-microprobe analyses of coralloid speleothems (wt \%).

\begin{tabular}{|l|r|r|r|r|r|r|r|r|}
\hline & 1 & \multicolumn{1}{c|}{2} & \multicolumn{1}{c|}{3} & \multicolumn{1}{c|}{4} & \multicolumn{1}{c|}{5} & \multicolumn{1}{c|}{6} & 7 & \multicolumn{1}{c|}{8} \\
\hline $\mathrm{SiO}_{2}$ & 89.83 & 91.94 & 88.98 & 97.36 & 91.41 & 88.58 & 92.61 & 92.92 \\
$\mathrm{TiO}_{2}$ & 0.00 & 0.00 & 0.00 & 0.00 & 0.00 & 0.00 & 0.00 & 0.00 \\
$\mathrm{Al}_{2} \mathrm{O}_{3}$ & 0.48 & 0.83 & 1.74 & 0.34 & 1.26 & 1.85 & 0.64 & 1.54 \\
$\mathrm{Cr}_{2} \mathrm{O}_{3}$ & 0.00 & 0.00 & 0.00 & 0.00 & 0.00 & 0.00 & 0.00 & 0.00 \\
$\mathrm{FeO}^{*}$ & 0.03 & 0.23 & 0.38 & 0.00 & 0.11 & 0.25 & 0.02 & 0.39 \\
$\mathrm{MgO}$ & 0.00 & 0.00 & 0.00 & 0.00 & 0.00 & 0.00 & 0.00 & 0.00 \\
$\mathrm{MnO}$ & 0.00 & 0.00 & 0.00 & 0.00 & 0.00 & 0.00 & 0.00 & 0.00 \\
$\mathrm{CaO}$ & 0.08 & 0.04 & 0.03 & 0.07 & 0.07 & 0.08 & 0.02 & 0.11 \\
$\mathrm{Na}{ }_{2} \mathrm{O}$ & 0.00 & 0.00 & 0.00 & 0.00 & 0.00 & 0.00 & 0.00 & 0.00 \\
$\mathrm{~K}_{2} \mathrm{O}$ & 0.00 & 0.00 & 0.00 & 0.00 & 0.00 & 0.00 & 0.00 & 0.00 \\
\hline $\mathrm{Total}$ & 90.43 & 93.03 & 91.13 & 97.77 & 92.86 & 90.76 & 93.29 & 94.96 \\
\hline
\end{tabular}

*Total $\mathrm{Fe}$ as $\mathrm{FeO}$ 

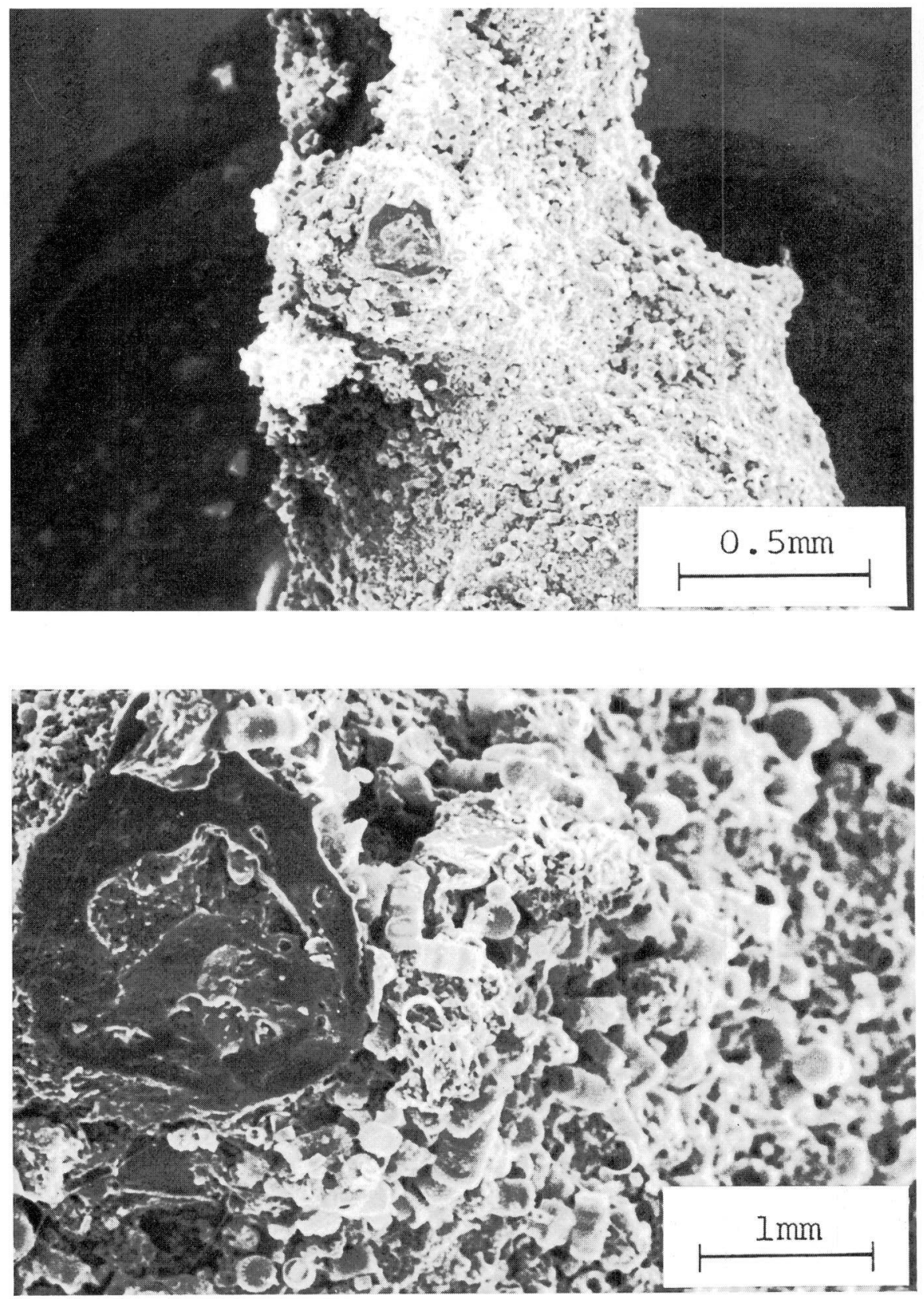

Fig. 2 - Scanning photomicrographs of the surface of coralloid speleothems showing increased magnification views of diatom (Melosira sp.) colonies. 

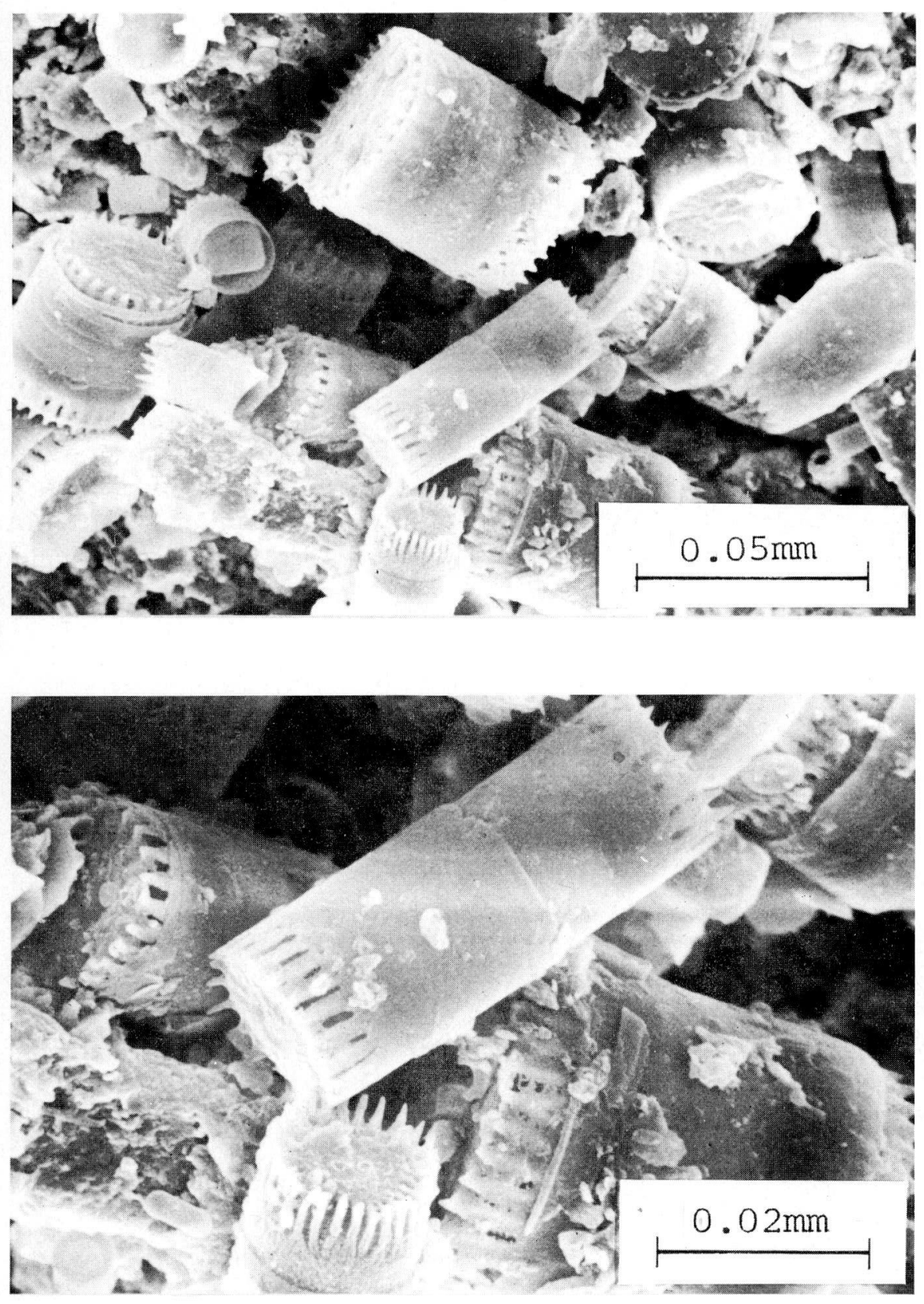

Fig. 3 - Scanning photomicrographs of the surface of coralloid speleothems showing increased magnification views of diatom (Melosira sp.) colonies. 
To our knowledge, diatom algae speleothems has not been reported from the cave environment. The common occurrence of diatom (genus Melosira) in Togawa-Sakaidani-do Cave, merging into concentric layers and covering up coralloid speleothems, suggests that coralloid speleothems growth is triggered, directry or indirectry, by the activities of diatom algae.

At the present stage, it is not possible to attest that the living diatom algae actually distributes on the surface of coralloid speleothems, cave walls and drip water, sothat this question must be subjected to future study.

It is to be hoped that the diatom algae speleothems in noncalcareous caves will encourage other researchers to the study of biogenic speleogenesis.

\section{ACKNOWLEDGEMENTS}

We are most grateful to Mr. Tadashi BANDO of Department of Botany, Faculty of Science, Hiroshima University for taxonomic identification of diatom. The writers also with to thank Mr. Yoshifumi KOOSAKA of Department of Earth Sciences, Faculty of Science, Ehime University for valuable electoron microprobe analysis.

\section{REFERENCES}

CubBon B.D., 1976: Cave flora, p. 423-452. In T.D. Ford and C. H. D. Cullingford (eds.), The Science of Speleology. Academic Press, New York.

Hill C. A. AND FORTI P., 1986: Cave minerals of the World. With a histrical introduction by T. R. Shaw. National Speleological Society, Huntsville.

KASHIMA N., 1986: Cave formations from noncalcareous caves in Kyushu, Japan. Comm. 9th Congr. Int. Speleol., 2:41-43.

METALLIC MineRALS ExPLORATION AgENCY OF JAPAN. 1967-1968: The report of regional survey. Sobo-Katamuki areas. The Ministry of International Trade and Industry, Tokyo. 